\title{
Contents IMIA Yearbook of Medical Informatics 2013
}

President's Statement

Obituaries

Keynote

Special Section: Evidence-based

Health Informatics

Survey

\section{Working Group Contributions}

A. Geissbuhler

Scaling up Health Informatics

P. Weber

Professor John Bryden

L. Hanmer

Sedick Isaacs

* The complete papers can be accessed in the Yearbook's full electronic version, provided that the article is freely accessible or that your institution has access to the respective journal. 
Section 1: Health and Clinical Management

Survey P. A. Abbott, Y. Liu

A Scoping Review of Telehealth

Regional Paper A. Moen, W. O. Hackl, J. Hofdijk, L. Van Gemert-Pijnen, E. Ammenwerth, P. Nykänen, A. Hoerbst ellealth in Europe - Status and Challenges

Synopsis N. Bricon-Souf, M.-C. Jaulent,

Trends on Integrating Technologies for Mobile and Personalized Care

Best Paper Selection Content summaries of :

Cillessen FH, de Vries Robbé PF. Modeling problem-oriented clinical notes. Methods Inf Med 2012 Dec 4;51(6):507-15

Jeong S, Youn CH, Shim EB, Kim M, Cho YM, Peng L. An integrated healthcare system for personalized chronic disease care in home-hospital environments. IEEE Trans Inf Technol Biomed 2012 Jul; 16(4):572-85

Klasnja P, Pratt W. Healthcare in the pocket: mapping the space of mobile-phone health interventions. J Biomed Inform 2012 Feb;45(1):184-98

Stenner SP, Johnson KB, Denny JC. PASTE: patient-centered SMS text tagging in a medication management system. J Am Med Inform Assoc 2012 May-Jun;19(3):368-74

Tawfik H, Anya 0, Nagar AK. Understanding clinical work practices for cross-boundary decision support in e-health. IEEE Trans Inf Technol Biomed 2012 Jul; 16(4):530-41

Section 2: Human Factors and Organizational Issues

Survey M.C. Beuscart-Zéphir, E. Borycki, P. Carayon, M.W.M. Jaspers, S. Pelayo Evolution of Human Factors Research and Studies of Health Information Technologies: The Role of Patient Safety

Working Group Contribution

Synopsis

Best Paper Selection

\section{A. Kushniruk, C. Nohr, S. Jensen, E. M. Borycki}

From Usability Testing to Clinical Simulations: Bringing Context into the Design and Evaluation of Usable and Safe Health Information Technologies

G. Declerck, X. Aimé

Why Medical Informatics (still) Needs Cognitive and Social Sciences

Content summaries of*:

Djulbegovic B, Hozo I, Beckstead J, Tsalatsanis A, Pauker SG. Dual processing model of medical decision-making. BMC Med Inform Decis Mak 2012 Sep 3;12:94

Li SY, Magrabi F, Coiera E. A systematic review of the psychological literature on interruption and its patient safety implications. J Am Med Inform Assoc 2012 Jan-Feb;19(1):6-12

Park SY, Lee SY, Chen Y. The effects of EMR deployment on doctors' work practices: a qualitative study in the emergency department of a teaching hospital. Int J Med Inform 2012 Mar;81(3):204-17

Pelayo S, Anceaux F, Rogalski J, Elkin P, Beuscart-Zephir MC. A comparison of the impact of CPOE implementation and organizational determinants on doctor-nurse communications and cooperation. Int J Med Inform 2012 Sep 20

Schraagen JM, Verhoeven F. Methods for studying medical device technology and practitioner cognition: The case of user-interface issues with infusion pumps. J Biomed Inform 2013 Feb;46(1):181-95

Tariq A, Georgiou A, Westbrook J. Medication errors in residential aged care facilities: A distributed cognition analysis of the information exchange process. Int J Med Inform 2013 May;82(5):299-312

\footnotetext{
* The complete papers can be accessed in the Yearbook's full electronic version, provided that the article is freely accessible or that your institution has access to the respective journal.
} 
Section 3: Health Information Systems

Survey D. Kalra, B. Fernando

A Review of the Empirical Evidence of the Healthcare Benefits of Personal Health Records

Regional Paper E. M. Borycki, D. Newsham, D. W. Bates

eHealth in North America

Working Group Contribution

Synopsis

Best Paper Selection

H. Schmuhl, 0. Heinze, B. Bergh

Use of Open Source Software in Health Care Delivery - Results of a Qualitative Field Study

L. Toubiana, M.Cuggia

Health Information Systems. Toward Evidence-based Health Information Systems?

Content summaries of :

Abramson E L, Patel V, Malhotra S, Pfoh E R, Osorio S N, Cheriff A, Cole C L, Bunce A, Ash J,

Kaushal R. Physician experiences transitioning between an older versus newer electronic health record for electronic prescribing. Int I Med Inform 2012;81(8):539-48

Hsu W, Taira R K, El-Saden S, Kangarloo H, Bui A. A T Context-Based Electronic Health Record: To-

ward Patient Specific Healthcare. IEEE Trans Inf Technol Biomed 2012;16(2):228-34

Klompas M, McVetta J, Lazarus R, Eggleston E, Haney G, Kruskal B A, Yih W K, Daly P, Oppedisano P, Beagan B, Lee M, Kirby C, Heisey-Grove D, DeMaria A Jr, Platt R. Integrating Clinical Practice and Public Health Surveillance Using Electronic Medical Record Systems. Am J Prev Med 2012;102:S325-S332

Palen T E, Ross C, Powers J D, Xu S. Association of Online Patient Access to Clinicians and Medical Records With Use of Clinical Services. JAMA 2012;308(19):2012-9

Prados-Suárez B, Molina C, Peña Yañez C, Prados de Reyes M. Contextualized Access to Electronical Health Records in Cardiology. IEEE Trans Inf Technol Biomed 2012;16(3):401-12

Section 4: Sensor, Signal and Imaging Informatics

Synopsis S. Voros, A. Moreau-Gaudry

Sensor, Signal, and Imaging Informatics: Evidence-Based Health Informatics

Best Paper Selection

Content summaries of*:

Baumann M, Mozer P, Daanen V, Troccaz J. Prostate biopsy tracking with deformation estimation. Med Image Anal 2012 Apr; 16(3):562-76

Deng Y, Wang Y, Shen Y, Chen P. Active cardiac model and its application on structure detection from early fetal ultrasound sequences. Comput Med Imaging Graph 2012 Apr;36(3):239-47

Padoy N, Blum T, Ahmadi SA, Feussner H, Berger MO, Navab N. Statistical modeling and recognition of surgical workflow. Med Image Anal 2012 Apr; 16(3):632-41

Shamir RR, Joskowicz L, Tamir I, Dabool E, Permman L, Ben-Ami A, Shoshan Y. Reduced risk trajectory planning in image-guided keyhole neurosurgery. Med Phys 2012 May;39(5):2885-95

Trebbels D, Fellhaver F, Jugl M, Haimerl G, Min M, Zengerle R. Online tissue discrimination for transcutaneous needle guidance applications using broadband impedance spectroscopy. IEEE Trans Biomed Eng 2012 Feb;59(2):494-503

* The complete papers can be accessed in the Yearbook's full electronic version, provided that the article is freely accesible or that your institution has access to the respective journal. 
VI

IMIA and Schattauer GmbH

Section 5: Decision Support

Survey R. N. Shiffman, A. Wright

Evidence-Based Clinical Decision Support

Synopsis J. Bouaud, J.-B. Lamy

A Medical Informatics Perspective on Clinical Decision Support Systems

Best Paper Selection Content summaries of :

Bright TJ, Wong A, Dhuriati R, Bristow E, Bastian L, Coeytaux RR, Samsa G, Hasselblad V, Williams

JW, Musty MD, Wing L, Kendrick AS, Sanders GD, Lobach D. Effect of clinical decision-support systems: a systematic review. Ann Intern Med 2012 Jul 3;157(1):29-43

Pruszydlo MG, Walk-Fritz SU, Hoppe-Tichy T, Kaltschmidt J, Haefeli WE. Development and evaluation of a computerised clinical decision support system for switching drugs at the interface between primary and tertiary care. BMC Med Inform Decis Mak 2012 Nov 27;12:137

Rattinger GB, Mullins CD, Zuckerman IH, Onukwugha E, Walker LD, Gundlapalli A, Samore M, Delisle $S$. A sustainable strategy to prevent misuse of antibiotics for acute respiratory infections. PLoS One 2012;7(12):e51147

Riaño D, Real F, López-Vallverdú JA, Campana F, Ercolani S, Mecocci P, Annicchiarico R, Caltagirone $C$. An ontology-based personalization of health-care knowledge to support clinical decisions for chronically ill patients. J Biomed Inform 2012 Jun;45(3):429-46

Tamblyn R, Eguale T, Buckeridge DL, Huang A, Hanley J, Reidel K, Shi S, Winslade N. The effectiveness of a new generation of computerized drug alerts in reducing the risk of injury from drug side effects: a cluster randomized trial. J Am Med Inform Assoc 2012 Jul-Aug; 19(4):635-43

Westbrook JI, Reckmann M, Li L, Runciman WB, Burke R, Lo C, Baysari MT, Braithwaite J, Day RO. Effects of two commercial electronic prescribing systems on prescribing error rates in hospital in-patients: a before and after study. PLoS Med 2012 Jan;9(1):e1001164

Section 6: Knowledge Representation and Management

Survey

S. Schulz, L. Jansen

Formal Ontologies in Biomedical Knowledge Representation

Working Group Contribution

H. Liyanage, S.-T. Liaw, C. Kuziemsky, A. L. Terry, S. Jones, J. K. Soler, S. de Lusignan The Evidence-base for Using Ontologies and Semantic Integration Methodologies to Support Integrated Chronic Disease Management in Primary and Ambulatory Care: Realist Review

Synopsis N. Griffon, J. Charlet, SJ. Darmoni

Knowledge Representation and Management: Towards an Integration of a Semantic Web in Daily Health Practice

Best Paper Selection Content summaries of*:

Koutkias V, Kilintzis V, Stalidis G, Lazou K, Niès J, Durand-Texte L, McNair P, Beuscart R, Maglaveras

$N$. Knowledge engineering for adverse drug event prevention: on the design and development of a uniform, contextualized and sustainable knowledge-based framework. J Biomed Inform 2012 Jun;45(3):495-506

Meizoso García M, Iglesias Allones JL, Martínez Hernández D, Taboada Iglesias MJ. Semantic similarity-based alignment between clinical archetypes and SNOMED CT: an application to observations. Int J Med Inform 2012 Aug;81(8):566-78

Patrick J, Li M. An ontology for clinical questions about the contents of patient notes. J Biomed Inform 2012 Apr;45(2):292-306

Teodoro D, Pasche E, Gobeill J, Emonet S, Ruch P, Lovis C. Building a transnational biosurveillance network using semantic web technologies: requirements, design, and preliminary evaluation. J Med Internet Res 2012 May 29;14(3):e73

* The complete papers can be accessed in the Yearbook's full electronic version, provided that the article is freely accessible or that your institution has access to the respective journal. 
Section 7: Education and Consumer Health Informatics

Survey M. C. Gibbons Personal Health and Consumer Informatics. The Impact of Health Oriented Social Media Applications on Health Outcomes

Working Group Contribution

T. Miron-Shatz, M. M. Hansen, F. J. Grajales III, F. Martin-Sanchez, P. D. Bamidis

Social Media for the Promotion of Holistic Self-Participatory Care: An Evidence Based Approach

Synopsis P. Staccini, N. Douali

Evidence-based Practice

Best Paper Selection

Content summaries of*:

Mulvaney D, Woodward B, Datta S, Harvey P, Vyas A, Thakker B, Farooq 0, Istepanian R. Monitoring heart disease and diabetes with mobile internet communications. Int J Telemed Appl 2012;2012:195970

Noblin AM, Wan TT, Fottler M. The impact of health literacy on a patient's decision to adopt a personal health record. Perspect Health Inf Manag 2012;9:1-13

Schreier G, Eckmann H, Hayn D, Kreiner K, Kastner P, Lovell N. Web versus app: compliance of patients in a telehealth diabetes management programme using two different technologies. J Telemed Telecare 2012;18(8):476-80

von Muhlen M, Ohno-Machado L. Reviewing social media use by clinicians. J Am Med Inform Assoc 2012 Sep-0ct; 19(5):777-81

Section 8: Bioinformatics and Translational Informatics

Survey

I.N. Sarkar

Bringing Genome Tests into Clinical Practice

Synopsis T. Lecroq, L. F. Soualmia

From Genome Sequencing to Bedside

Best Paper Selection Content summaries of*:

Harrow J, Frankish A, Gonzalez JM, Tapanari E, Diekhans M, Kokocinski F, Aken BL, Barrell D, Zadissa A, Searle S, Barnes I, Bignell A, Boychenko V, Hunt T, Kay M, Mukherjee G, Rajan J, Despacio-Reyes G, Saunders G, Steward C, Harte R, Lin M, Howald C, Tanzer A, Derrien T, Chrast J, Walters N, Balasubramanian S, Pei B, Tress M, Rodriguez JM, Ezkurdia I, van Baren J, Brent M, Haussler D, Kellis M, Valencia A, Reymond A, Gerstein M, Guigó R, Hubbard TJ. GENCODE: the reference human genome annotation for The ENCODE Project. Genome Res 2012 Sep;22(9):1760-74

Leary RJ, Sausen M, Kinde I, Papadopoulos N, Carpten JD, Craig D, O'Shaughnessy J, Kinzler KW, Parmigiani G, Vogelstein B, Diaz LA Jr, Velculescu VE. Detection of chromosomal alterations in the circulation of cancer patients with whole-genome sequencing. Sci Transl Med 2012 Nov 28;4(162):162ral 154 Stubbs A, McClellan EA, Horsman S, Hiltemann SD, Palli I, Nouwens S, Koning AH, Hoogland F, Reumers J, Heijsman D, Swagemakers S, Kremer A, Meijerink J, Lambrechts D, van der Spek PJ. nHuvariome: a web server resource of whole genome next-generation sequencing allelic frequencies to aid in pathological candidate gene selection. J Clin Bioinforma 2012 Nov 19;2(1):19

Tennessen JA, Bigham AW, O'Connor TD, Fu W, Kenny EE, Gravel S, McGee S, Do R, Liu X, Jun G, Kang HM, Jordan D, Leal SM, Gabriel S, Rieder MJ, Abecasis G, Altshuler D, Nickerson DA, Boerwinkle E, Sunyaev S, Bustamante CD, Bamshad MJ, Akey JM; Broad G0; Seattle G0; NHLBI Exome Sequencing Project. Evolution and functional impact of rare coding variation from deep sequencing of human exomes. Science 2012 Jul 6;337(6090):64-9

* The complete papers can be accessed in the Yearbook's full electronic version, provided that the article is freely accessible or that your institution has access to the respective journal. 
Section 9: Clinical Research Informatics

Survey

P. J. Embi

Clinical Research Informatics: Survey of Recent Advances and Trends in a Maturing Field

Synopsis C. Daniel, R. Choquet,

Information Technology for Clinical, Translational and Comparative Effectiveness Research

Best Paper Selection Content summaries of*:

Eder J, Gottweis H, Zatloukal K. IT solutions for privacy protection in biobanking. Public Health Genomics 2012; 15(5):254-62

Jensen PB, Jensen $\amalg$, Brunak S. Mining electronic health records: towards better research applications and clinical care. Nat Rev Genet 2012 Jun;13(6):395-405

Sittig DF, Hazlehurst BL, Brown J, Murphy S, Rosenman M, Tarczy-Hornoch P, Wilcox AB. A survey of informatics platforms that enable distributed comparative effectiveness research using multi-institutional heterogeneous clinical data. Med Care 2012 Jul;50 Suppl:S49-59

Tasneem A, Aberle L, Ananth H, Chakraborty S, Chiswell K, McCourt BJ, Pietrobon R. The database for aggregate analysis of ClinicalTrials.gov (AACT) and subsequent regrouping by clinical specialty. Plos One 2012;7(3):e33677

Research \& Education

History of Medical Informatics

Information on IMIA

Information on IMIA Regions

\section{Bouhaddou, M. Bennani Othmani, S. Diouny}

Medical Informatics in Morocco

\section{Korpela}

Two decades of HELINA Conferences: A Historical Review of Health Informatics in Africa

\section{J. Zvárová}

Medical Decision Support and Medical Informatics Education: Roots, Methods and Applications

in Czechoslovakia and the Czech Republic

Information on IMIA

Honorary Fellows

IMIA Member Societies

Institutional Members

Addresses of IMIA Member Societies

Information on APAMI (Asia Pacific Association for Medical Informatics)

Information on Helina (African Region)

Information on IMIA-LAC (Federation of Health Societies in Latin America)

Information on MEAHI (Middle East Association of Health Informatics)

Information on North-American Medical Informatics (NAMI)

Information on EFMI (European Federation For Medical Informatics)

Information on EFMI Working Groups

Contributors

MIA Yearbook Special Topics

Impressum

* The complete papers can be accessed in the Yearbook's full electronic version, provided that the article is freely accessible or that your institution has access to the respective journal. 